\title{
SISTEM INFORMASI DATA KEUANGAN LAPORAN AKUNTABILITAS KINERJA INSTANSI PEMERINTAH (LAKIP) POLITEKNIK NEGERI MALANG
}

\author{
Raphael Nugraha $\mathbf{W}^{1}$, Siti Romlah ${ }^{2}$, Ulla Delfana Rosiani ${ }^{3}$ \\ ${ }^{1,2}$, Program Studi Teknik Informatika, Jurusan Teknik Elektro, ${ }^{3}$ Politeknik Negeri Malang \\ ${ }^{1}$ rafaelnugraha@gmail.com ${ }^{2}$ sihalmor@gmail.com ${ }^{3}{ }^{3}$ _ulla@yahoo.com
}

\begin{abstract}
Abstrak
Dalam penelitian ini akan dibuat Sistem Informasi Data Keuangan Laporan Akuntabilitas Kinerja (LAKIP) Politeknik Negeri Malang berbasis web untuk mempermudah dalam penyusunan Laporan Akuntabilitas Kinerja pada Politeknik Negeri Malang di buat menjadi sebuah Sistem Informasi secara LAN(Local Area Network). Sistem Informasi ini menggunakan bahasa pemrograman PHP yang diguankan untuk mengembangkan perangkat dan menggunakan mysql sebagai database.Hasil pembuatan sistem informasi ini bertujuan untuk membuat Sistem Akuntabilitas Kinerja Instansi Pemerintah yang berada di Politenik Negeri Malang pentingnya sistem informasi dalam Sistem Akuntabilitas Instansi Pemerintah untuk mempermudah melihat data keuangan LAKIP yang sebelumnya data LAKIP masih berbentuk manual. Hasil Sistem Informasi Akuntabilitas Kinerja Instansi Pemerintah mempermudah dalam memasukan data, melihat data dan melihat diagaram untuk mengetahui data tiap tahunnya dengan Sistem Informasi ini di harapkan dapat membantu dalam pembuatan Laporan Akuntabilitas Kinerja Instansi Pemerintah (LAKIP).
\end{abstract}

Kata kunci: skripsi, lakip, sistem informasi, data, keuangan

\section{Pendahuluan}

Sistem Informasi Data Keuangan Laporan Akuntabilitas Kinerja Instansi Pemerintah mempunyai peranan penting dalam penyusunan Laporan Akuntabilitas Kinerja Instansi Pemerintah (LAKIP). Sistem informasi ini dibangun berbasis web yang berfungsi untuk mempermudah mengelolah dan melaporkan informasi data keuangan dalam instansi pemerintah.

Sistem Informasi Data Keuangan Laporan Akuntabilitas Kinerja Instansi Pemerintah membutuhkan data keuangan berupa rencana anggaran dan realisasi anggaran instansi pemerintah yang akan dijadikan acuan utama dalam penyusunan Laporan Akuntabilitas Kinerja Instansi Pemerintah (LAKIP) pada setiap tahunnya untuk dapat mengukur efisiensi anggaran atau penghematan anggaran serta anggaran yang telah dicapai oleh instansi pemerintah. Setiap rencana anggaran dan realisasi anggaran disusun berdasarkan indikator kinerja dan sasaran strategis yang telah ditentukan oleh instansi pemerintah dalam penyususnan Laporan Akuntabilitas Kinerja Instansi Pemerintah (LAKIP).

Laporan Akuntabilitas Kinerja Instansi Pemerintah (LAKIP) wajib disusun oleh Instansi Pemerintah di tingkat pusat maupun daerah untuk mempertanggungjawabkan penyelenggara pemeritah dan pelaksanaan yang tepat, jelas, terukur dan akuntabel berdasarkan Instruksi Presiden Nomor 7 Tahun 1999 tentang Akuntabilitas Kinerja Instansi Pemerintah disertai Keputusan Kepala Lembaga Administrasi Negara Nomor 589/IX/6/Y/99 tentang Pedoman Penyusunan Pelaporan Akuntabilitas Kinerja Instansi Pemerintah dan telah disempurnakan dalam Keputusan Kepala Lembaga Administrasi Negara Nomor 239/IX/6/8/2003 tentang Perbaikan Pedoman Penyusunan Pelaporan Akuntabilitas Kinerja Instansi Pemerintah, disebutkan bahwa Laporan Akuntabilitas Kinerja Instansi Pemerintah merupakan alat untuk melaksanakan akuntabilitas kinerja instansi pemerintah. Dan LAKIP sendiri merupakan bagian dari sebuah Sistem Akuntabilitas Kinerja Instansi Pemerintah yang bertujuan untuk mendorong terciptanya akuntabilitas kinerja instansi pemerintah sebagai salah satu prasyarat untuk terciptanya pemerintah yang baik dan terpercaya termasuk dalam lembaga pendidikan tinggi.

Pada lembaga pendidikan tinggi penerapan Laporan Akuntabilitas Kinerja Instansi Pemerintah (LAKIP) dapat membantu pendidikan untuk melaporkan kinerja lembaga pendidikan tinggi melalui data keuangan di setiap indikator kerja 
yang telah ditentukan seperti perkembangan sarana prasarana, dana beasiswa dan sebagainya.

Tetapi dalam kenyataannya proses penyusunan laporan akuntabilitas kinerja instansi pemerintah mengalami beberapa permasalahan. Permasalahan yang muncul antara lain terlambat dalam ketepatan waktu pengumpulan data keuangan, kurang akurat dalam perhitungan anggaran, penyimpanan data untuk menjadi pembanding tahunan, transparansi dan publikasi, penyajian dan pencarian data yang kurang efektif dan efisien sebagai akibat karena masih menggunakan cara lama yaitu cara manual.

Untuk mengatasi masalah yang timbul maka perlu dibangun suatu Sistem Informasi Data Keuangan Laporan Akuntabilitas Kinerja Instansi Pemerintah dengan tujuan mempermudah para penyusun Data Keuangan Laporan Akuntabilitas Kinerja Instansi Pemerintah (LAKIP) dalam menyusun dan mengakses laporannya yang dapat diterapkan secara efektif dan efisien sebagai jawaban atas permasalahan yang ada seperti dalam Politeknik Negeri Malang.

\section{Metode}

\subsection{Kerangka Konsep Penelitian}

Aplikasi Sistem Informasi Data Keuangan Laporan Akuntabilitas Kinerja Instansi Pemerintah mempunyai kerangka konsep sebagai berikut:

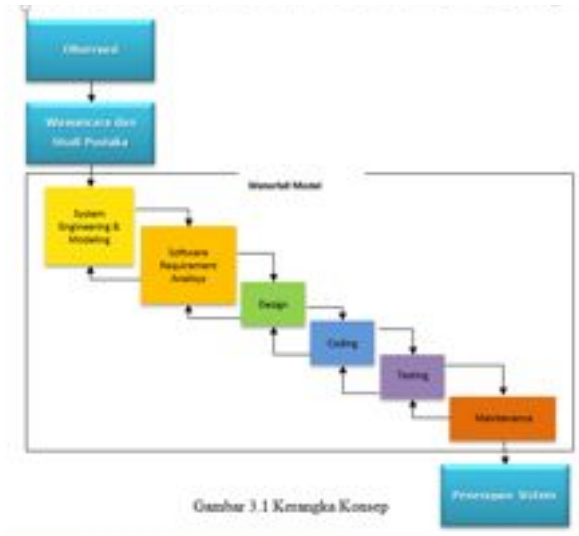

Gambar 2.1 Kerangka Konsep

\subsection{Tahap Penelitian}

\subsubsection{Observasi (pengamatan langsung)}

Melakukan pengamatan langsung ke tempat objek pembahasan yang ingin diperoleh yaitu melalui bagian-bagian terpenting dalam pengambilan data yang diperlukan.

\subsubsection{Wawancara}

Melakukan wawancara dengan DRA.Siti Romlah,MM sebagai staff penyusun laporan akuntabilitas kinerja instansi pemerintah di Politeknik Negeri Malang untuk mendapatkan penjelasan dari masalah-masalah yang ada dan untuk menyakinkan bahwa data yang diperoleh atau dikumpulkan benar-benar akurat yang berkaitan dengan perancangan dan pembangunan aplikasi.

\subsubsection{Studi Pustaka}

Studi Pustaka adalah aktivitas pemilihan suatu masalah yang akan digunakan sebagai tema penelitian. Kemudian diteruskan dengan pencarian referensi sebagai landasan teori dan penunjang terhadap proses pengerjaan sekaligus sebagai pemecahan masalah yang dihadapi dalam penelitian. Pada tahap ini penelitian dilakukan dengan mempelajari berbagai literatur melalui pengumpulan dokumen-dokumen, referensireferensi, buku-buku, sumber dari internet, atau sumber lain yang diperlukan untuk perancangan dan pembangunan aplikasi.

\subsection{Tahap Perancangan Sistem}

Metode pengembangan sistem yang digunakan penulis adalah metode pengembangan sistem Waterfall. Waterfall adalah sebuah sistem yang melakukan pendekatan secara sistematis dan terurut mulai dari level rekayasa perangkat lunak lalu menuju ke analisis, perancangan, implementasi, pengujian dan pemeliharaan. Disebut dengan waterfall karena tahap demi tahap yang dilalui harus menunggu selesainya tahap sebelumnya dan berjalan berurutan.

Berikut penjelasan tahapan-tahapan yang dilalui :

\subsubsection{Rekayasa dan Pemodelan Sistem (System Engineering \& Modeling)}

Permodelan ini diawali dengan mencari kebutuhan dari keseluruhan sistem yang akan diaplikasikan ke dalam bentuk software. Hal ini sangat penting, mengingat software harus dapat berinteraksi dengan elemen-elemen yang lain seperti hardware, database, dan sebagainya. Tahap ini sering disebut dengan Project Definition.

\subsubsection{Analisis Kebutuhan Perangkat Lunak (Software Requirement Analysis)}

Proses pencarian kebutuhan diintensifkan dan difokuskan pada software. Untuk mengetahui sifat dari program yang akan dibuat, maka para software 
engineer harus mengerti tentang domain informasi dari software, misalnya fungsi yang dibutuhkan, user interface serta masukan (input), proses, dan keluaran (output), berikut uraian penjelasannya :

\section{a. Masukan (Input)}

Data masukan yang diperlukan berupa data-data LAKIP. Data LAKIP tersebut adalah data yang akan dimasukkan oleh user saat menggunakan sistem yang merupakan data fisik LAKIP di Politeknik Negeri Malang.

\section{b. Proses}

Berupa proses yang dibutuhkan untuk mengolah data input menjadi output yang berupa informasi yang diharapkan. Data yang akan diproses menjadi hasil berupa diagram statistika. Kemudian dari hasil diagram statistika didapatkan informasi untuk melihat perkembangan kinerja di Politeknik Negeri Malang tiap tahunnya.

\section{c. Keluaran (Output)}

Sistem yang dibangun akan menghasilkan keluaran (output) berupa hasil perhitungan anggaran untuk melihat keuangan di Politenik Negeri Malang.

\subsubsection{Perancangan Perangkat Lunak (Design)}

Proses ini digunakan untuk mengubah kebutuhankebutuhan diatas menjadi representasi ke dalam bentuk "blueprint" software sebelum coding dimulai. Desain harus dapat mengimplementasikan kebutuhan yang telah disebutkan pada tahap sebelumnya.

\subsubsection{Pengkodean (Coding)}

Untuk dapat dimengerti oleh mesin, dalam hal ini adalah komputer, maka desain tadi harus diubah bentuknya menjadi bentuk yang dapat dimengerti oleh mesin, yaitu ke dalam bahasa pemrograman melalui proses coding. Tahap ini merupakan implementasi dari tahap design yang secara teknis nantinya dikerjakan oleh programmer.

\subsubsection{Pengujian Perangkat Lunak (Testing)}

Sesuatu yang dibuat haruslah diujicobakan. Demikian juga dengan software. Semua fungsifungsi software harus diujicobakan, agar software bebas dari error, dan hasilnya harus benar-benar sesuai dengan kebutuhan yang sudah didefinisikan sebelumnya.

\subsubsection{Pemeliharaan Perangkat Lunak}

(Maintenance)
Pemeliharaan suatu software diperlukan, termasuk di dalamnya adalah pengembangan, karena software yang dibuat tidak selamanya hanya seperti itu. Ketika dijalankan mungkin saja masih ada masalah kecil yang tidak itemukan sebelumnya, atau ada penambahan fitur-fitur yang belum ada pada software tersebut. Pengembangan diperlukan ketika adanya perubahan dari eksternal perusahaan seperti ketika ada pergantian sistem operasi, atau perangkat lainnya.

\section{Hasil}

Hasil dari Perancangan dan Pembangunan Sistem Informasi Data Keuangan Laporan Akuntabilitas Kinerja Instansi Pemerintah Politeknik Negeri Malang.

\subsection{Login}

Pengguna diminta untuk memasukkan nala pengguna dan kata sandi, jika nama pengguna terdaftar, pengguna dapat masuk ke sistem.

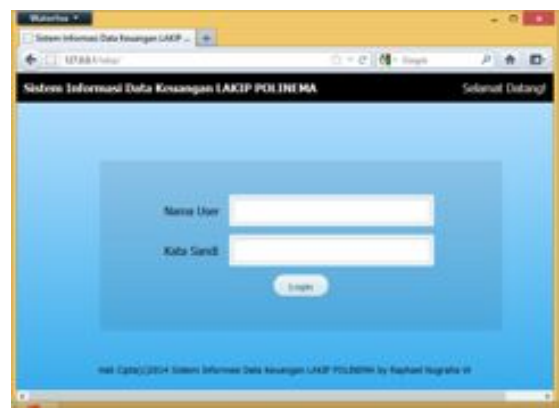

\subsection{Beranda}

Gambar 3.1 Tampilan Login

Tampilan awal setelah pengguna masuk ke sistem. Disini pengguna dapat melakukan aktivitas seperti mengelola sasaran strategis, indikator kerja dan anggaran.

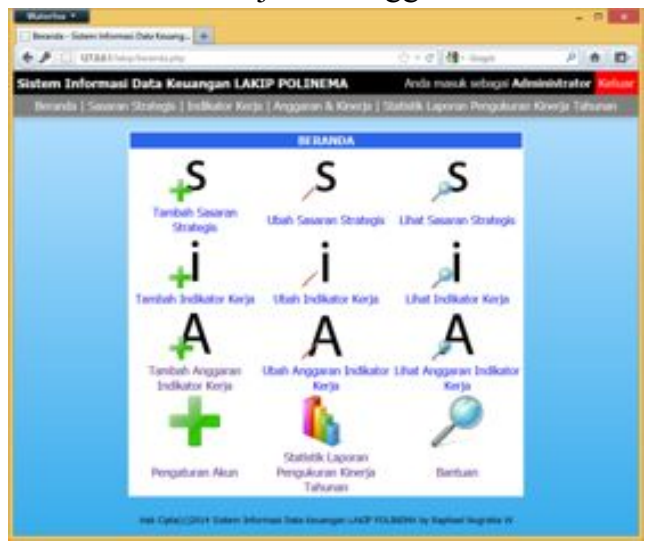

Gambar 3.2 Tampilan Beranda 
Pengguna dapat memasukan judul sasaran strategis, keterangan dan indeks urutan.

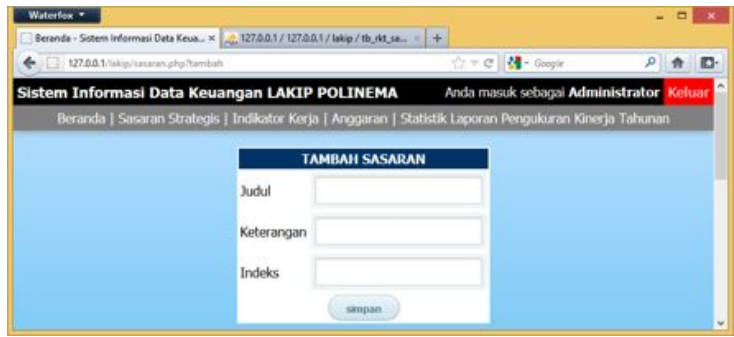

Gambar 3.3.1 Tampilan Tambah Sasaran Strategis

Pengguna juga dapat mengubah judul, keterangan dan indeks sasaran.

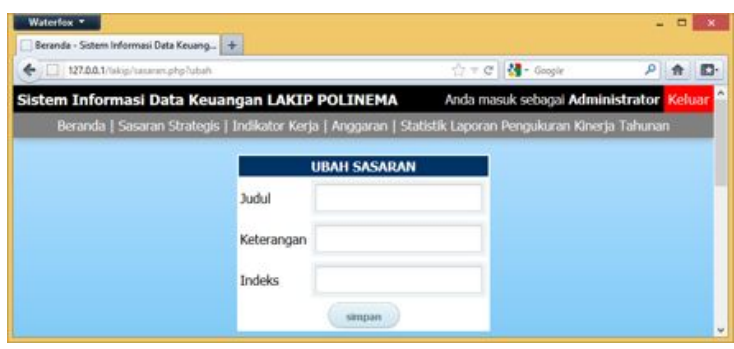

Gambar 3.3.2 Tampilan Ubah Sasaran Strategis

Pengguna dapat melihat hasil keluaran sasaran strategis dari yang telah dimasukkan ke dalam sistem.

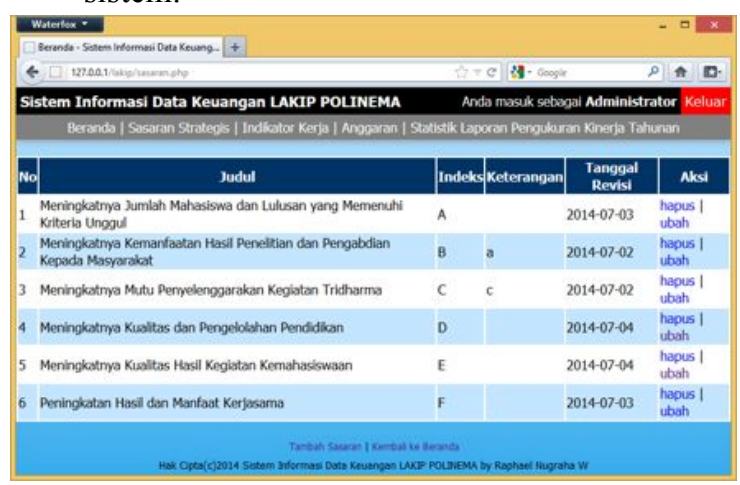

Gambar 3.3.3 Tampilan Lihat Sasaran Strategis

\subsection{Indikator Kerja}

Pengguna dapat memasukan judul, keterangan dan indeks urutan dari Indikator Kerja.

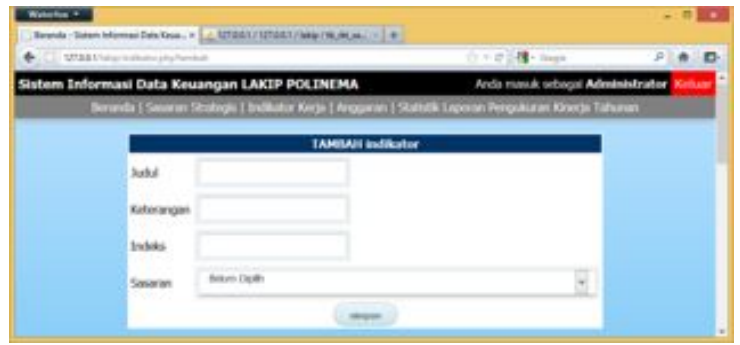

Gambar 3.4.1 Tampilan Tambah Indikator Kerja
Pengguna juga dapat mengubah judul, keterangan dan indeks indikator kerja.

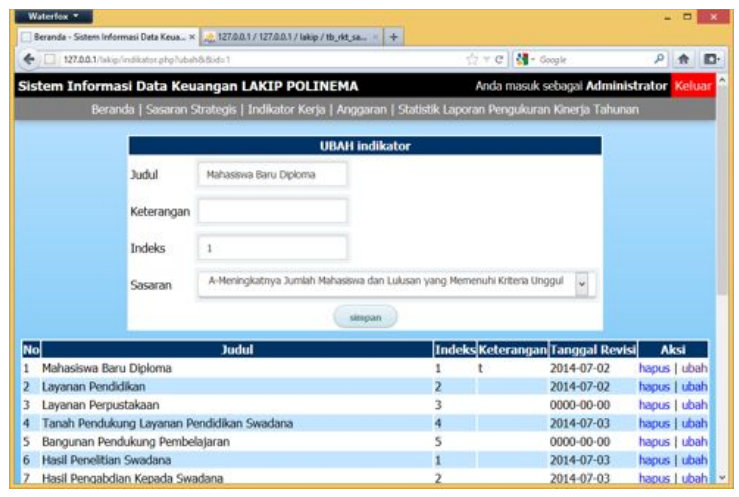

Gambar 3.4.2 Tampilan Ubah Indikator Kerja

Pengguna dapat melihat hasil keluaran indikator kerja dari yang telah dimasukkan ke dalam sistem.

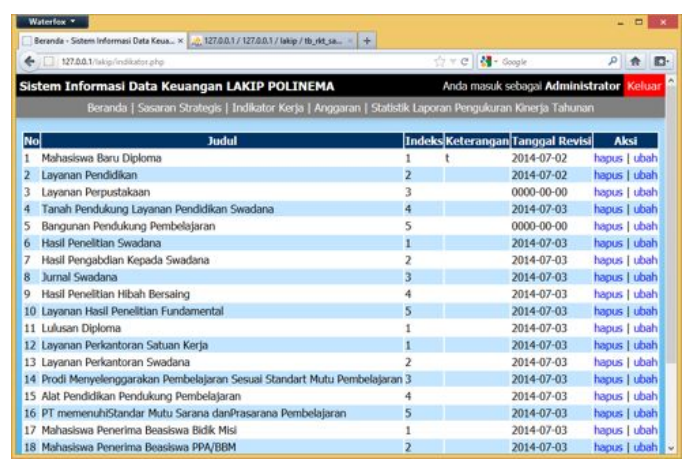

Gambar 3.4.3 Tampilan Lihat Indikator Kerja

\subsection{Anggaran Perencanaan dan Realisasi}

Pengguna dapat memasukan judul, anggaran pagu dan realisasi dan indeks urutan dari halaman anggaran.

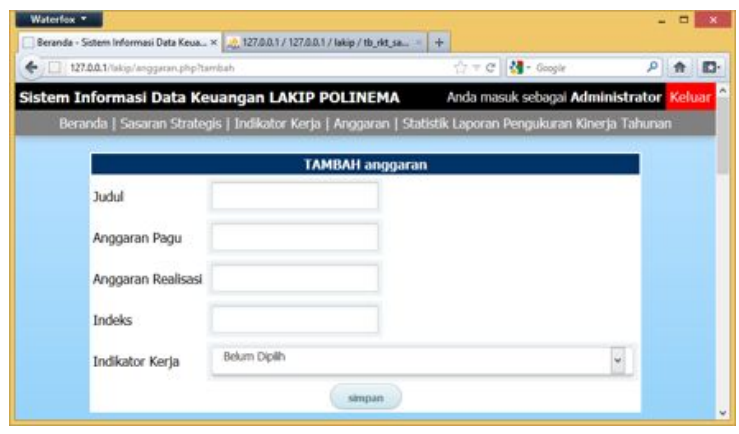

Gambar 3.5.1 Tampilan Tambah Anggaran

Pengguna dapat mengubah judul, anggaran pagu dan realisasi dan indeks urutan dari halaman anggaran. 


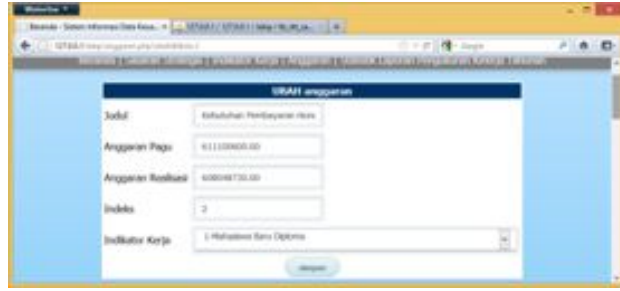

Gambar 3.5.2 Tampilan Ubah Anggaran

Pengguna dapat melihat hasil yang telah dimasukkan ke dalam sistem di halaman anggaran.

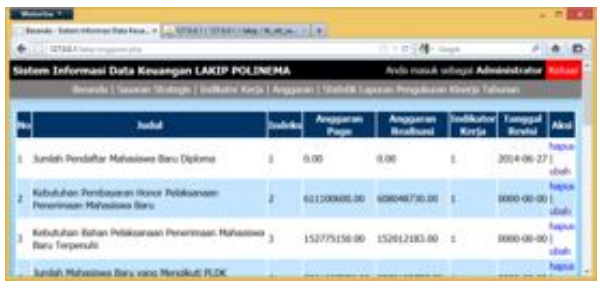

Gambar 3.5.2 Tampilan Lihat Anggaran

\subsection{Statistik Laporan Pengukuran Kinerja}

\section{Tahunan}

Pengguna dapat melihat tabel dan diagram pengukuran kinerja tahunan. DI dalam tabel juga diukur efisiensi dalam bentuk anggaran maupun persentasi.

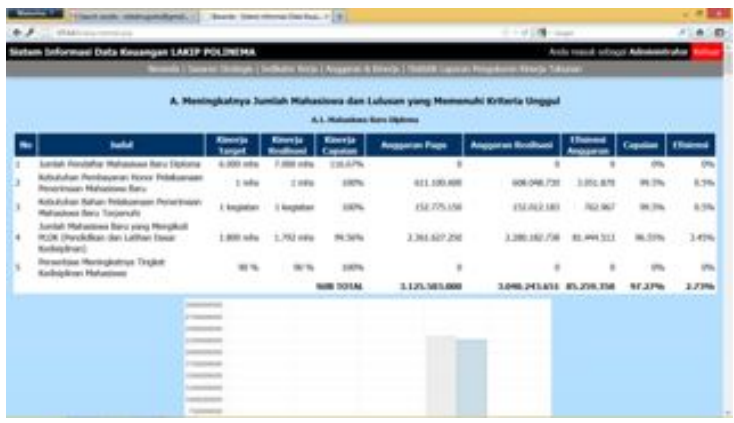

Gambar 3.6 Tampilan Pengukuran Kerja Tahunan berdasarkan tabel dan diagram

\subsection{Pengaturan Akun Pengguna}

Pengguna dapat menambahkan pengguna lebih dari satu.

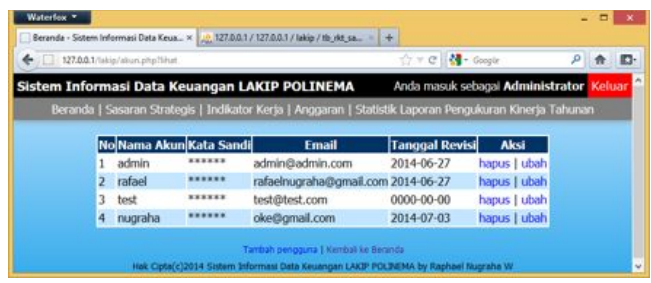

Gambar 3.7 Tampilan Pengaturan Akun Pengguna

\section{Pembahasan}

\subsection{Perancangan Usecase}

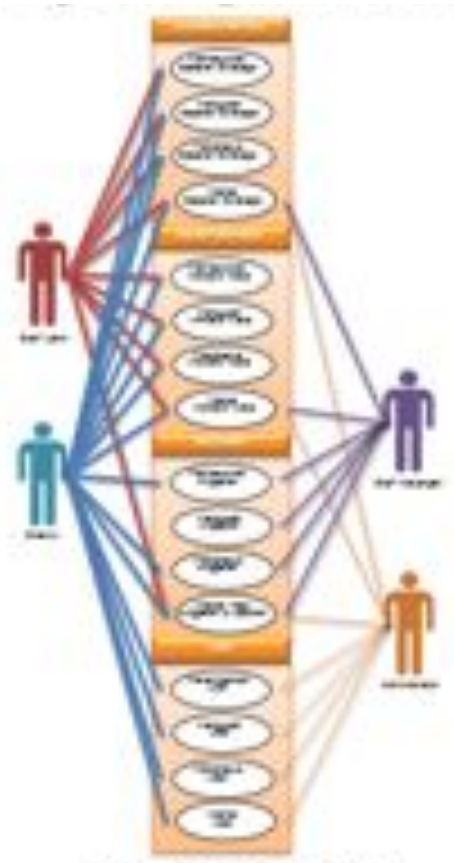

Gambar 4.1 Diagram Usecase

\subsection{Perancangan Database}

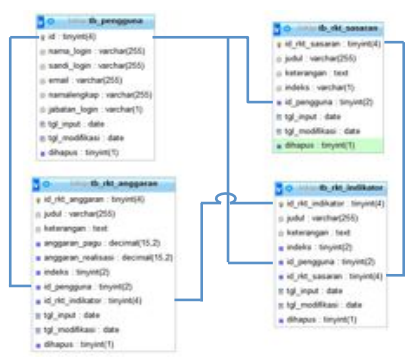

Gambar 4.2 Diagram Databse (ERD)

\subsection{Perancangan Tampilan}

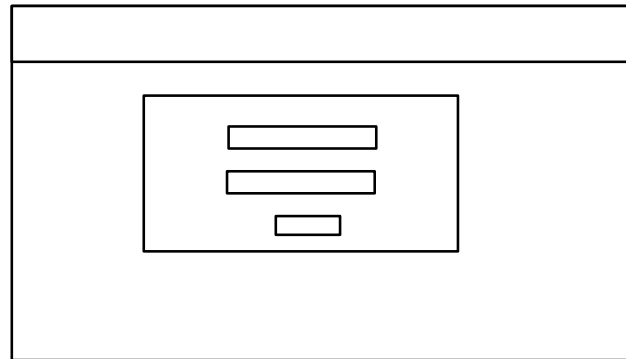

Gambar 4.3.1 Rancangan tampilan Login

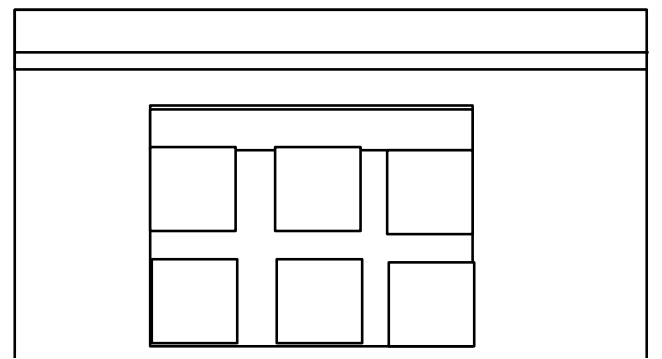


Gambar 4.3.2 Rancangan tampilan Beranda

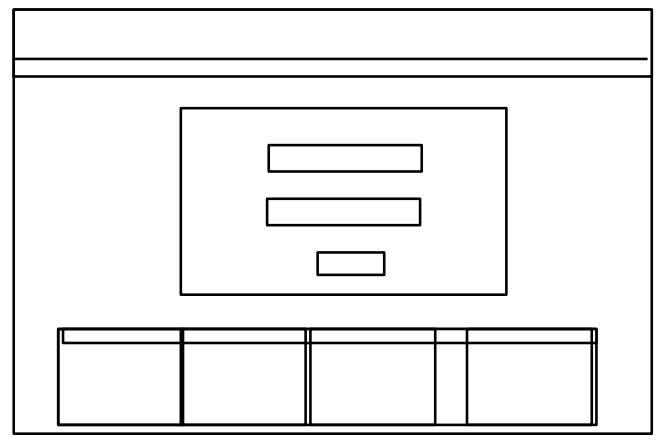

Gambar 4.3.3 Rancangan tampilan Input

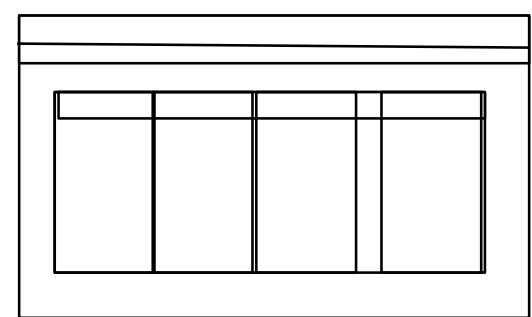

Gambar 4.3.4 Rancangan tampilan View

\subsection{Perhitungan}

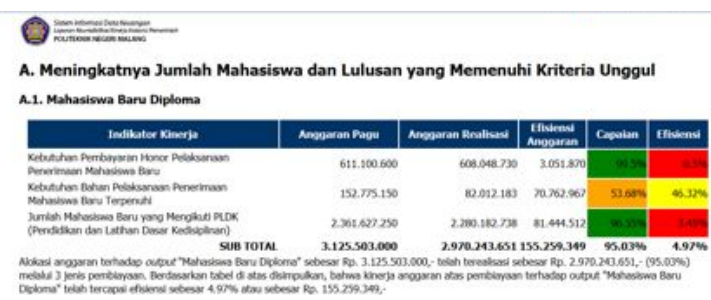

Gambar 4.4.2 Tampilan Ubah Anggaran

1. Capaian Kinerja $=$

(Realisasi Kinerja/Target Kinerja) x 100\%

2. Efisiensi Anggaran

Anggaran Pagu - Anggaran Realisasi

3. Capaian Anggaran

(Anggaran Realisasi/Anggaran Pagu) x 100\%

4. Efisiensi Anggaran

((Anggaran Pagu-Anggaran Realisasi)/Anggaran Pagu) $\times 100 \%$

\subsection{Pengujian}

Pengujian yang digunakan untuk menguji aplikasi ini adalah metode pengujian black box. Pengujian black box berfokus pada ujicoba fungsional perangkat lunak.
1. Rencana Pengujian

\begin{tabular}{|l|l|l|}
\hline No & Atribut & Keterangan \\
\hline 1 & Otentikasi Pengguna & $\begin{array}{l}\text { Memasukan } \\
\text { Nama } \\
\text { Pengguna dan } \\
\text { Kata Sandi }\end{array}$ \\
\hline 2 & Sasaran Strategis & $\begin{array}{l}\text { Create, Read, } \\
\text { Update, } \\
\text { Delete }\end{array}$ \\
\hline 3 & Indikator Kerja & $\begin{array}{l}\text { Create, Read, } \\
\text { Update, } \\
\text { Delete }\end{array}$ \\
\hline 4 & Anggaran & $\begin{array}{l}\text { Create, Read, } \\
\text { Update, } \\
\text { Delete }\end{array}$ \\
\hline 5 & $\begin{array}{l}\text { Laporan Pengukuran } \\
\text { Kinerja Tahunan }\end{array}$ & $\begin{array}{l}\text { Proccess, } \\
\text { Read }\end{array}$ \\
\hline 6 & Pengaturan Akun & $\begin{array}{l}\text { Create, Read, } \\
\text { Update, } \\
\text { Delete }\end{array}$ \\
\hline
\end{tabular}

2. Hasil Pengujian

\begin{tabular}{|c|c|c|c|}
\hline No & Atribut & Keterangan & Hasil \\
\hline 1 & $\begin{array}{l}\text { Otentikasi } \\
\text { Pengguna }\end{array}$ & $\begin{array}{l}\text { Memasukan } \\
\text { Nama } \\
\text { Pengguna } \\
\text { dan Kata } \\
\text { Sandi }\end{array}$ & Diterima \\
\hline \multirow[t]{4}{*}{2} & \multirow{4}{*}{$\begin{array}{l}\text { Sasaran } \\
\text { Strategis }\end{array}$} & Create & Diterima \\
\hline & & Read & Diterima \\
\hline & & Update & Diterima \\
\hline & & Delete & Diterima \\
\hline \multirow[t]{4}{*}{3} & \multirow{4}{*}{$\begin{array}{l}\text { Indikator } \\
\text { Kerja }\end{array}$} & Create & Diterima \\
\hline & & Read & Diterima \\
\hline & & Update & Diterima \\
\hline & & Delete & Diterima \\
\hline \multirow[t]{4}{*}{4} & \multirow[t]{4}{*}{ Anggaran } & Create & Diterima \\
\hline & & Read & Diterima \\
\hline & & Update & Diterima \\
\hline & & Delete & Diterima \\
\hline \multirow[t]{2}{*}{5} & \multirow{2}{*}{$\begin{array}{l}\text { Laporan } \\
\text { Pengukuran } \\
\text { Kinerja } \\
\text { Tahunan }\end{array}$} & Proccess & Diterima \\
\hline & & Read & Diterima \\
\hline \multirow[t]{4}{*}{6} & \multirow{4}{*}{$\begin{array}{l}\text { Pengaturan } \\
\text { Akun }\end{array}$} & Create & Diterima \\
\hline & & Read & Diterima \\
\hline & & Update & Diterima \\
\hline & & Delete & Diterima \\
\hline
\end{tabular}

\section{$5 \quad$ Penutup}

\subsection{Kesimpulan}

Berdasarkan hasil penelitian yang telah dilakukan, maka dapat ditarik kesimpulan sebagai berikut :

1. Sistem Informasi ini dibangun untuk menghimpun data keuangan Laporan 
Akuntabilitas Kinerja Instansi Pemerintah (LAKIP) di POLINEMA, merekam perubahan yang terjadi serta menyimpannya dalam satu himpunan data yang disebut dengan database.

2. Dari database tersebut bisa dijadikan sumber data dalam pembuatan Data Keuangan Laporan Akuntabilitas Kinerja Instansi Pemerintah (LAKIP) maupun output yang dapat dijadikan informasi untuk mengetahui tercapainya data keuangan.

3. Memberikan informasi yang cepat, tepat dan akurat mengenai data Laporan Akuntabilitas Kinerja Instansi Pemerintah (LAKIP).

4. Kesalahan atau data yang kurang valid dapat dimonitor dan dikoreksi dengan cepat.

\subsection{Saran}

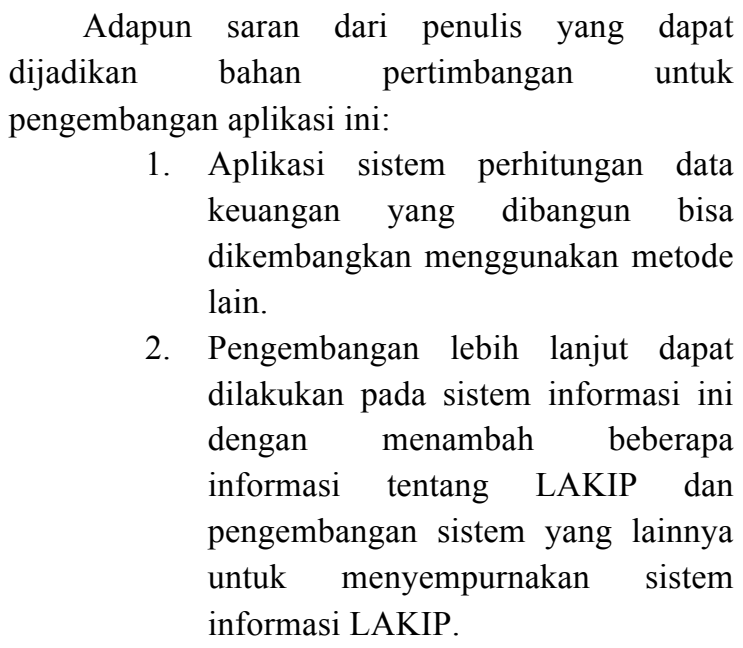

\section{Daftar Pustaka:}

Kadir, Abdul. 2010. Mudah Mempelajari Database MySQL. Yogyakarta: Penerbit ANDI.

Kusumadewi, Sri. 2003. Artificial Intelligence (Teknik dan Aplikasinya). Yogyakarta: Graha Ilmu.

Peranginangin, Kasiman. 2006. Aplikasi Web dengan PHP dan MySQL. Yogyakarta: ANDI

Stendy, B.Sakur. 2010. Konsep dan Implementasi Pemrograman berorientasi objek PHP 5. Yogyakarta: Penerbit ANDI.

Suyanto, Asep Herman. 2007. Step by Step Web Design theory and practices. Yogyakarta: Penerbit ANDI.

\section{Lampiran}

Profil penulis:
Raphael Nugraha W lahir di Malang tanggal 20 Mei 1992. Pada tahun 2010 penulis menamatkan pendidikan di SMK Negeri 8 Malang jurusan Teknik Komputer dan Jaringan kemudian melanjutkan pendidikan ke Politeknik Negeri Malang jurusan Teknik Elektro program studi Teknik Informatika. 